To Maega | Jurnal Pengabdian Masyarakat

Agustus 2021, Vol.4, No.2, hal, 170-178

$\operatorname{ISSN}(P): 2622-6332 ; \operatorname{ISSN}(E): 2622-6340$

http://www.ojs.unanda.ac.id/index.php/tomaega

\title{
Pelatihan Pengolahan Pangan Lokal Sumber Protein Untuk Meningkatkan Status Gizi Balita Di Kampung Nelayan Oesapa Kupang
}

\author{
Astuti Nur 1, ${ }^{1}$, Yualeni Valensia ${ }^{1}$, Marselina Yuliana A Lobo ${ }^{1}$ \\ ${ }^{1}$ Program Studi Gizi Politeknik Kesehatan Kementerian Kesehatan Kupang \\ *Correspondent Email: astutinur1989@gmail.com
}

Article History:

Received: 30-04-2021; Received in Revised: 20-05-2021; Accepted: 03-06-2021

DOI: http://dx.doi.org/10.35914/tomaega.v4i2.742

\begin{abstract}
Abstrak
Provinsi Nusa Tenggara Timur masih menempati urutan pertama dalam masalah gizi balita (wasting, stunting, dan underweight). Faktor penyebab masalah gizi pada balita diantaranya pengolahan makanan dan pengasuhan anak yang tidak memadai. Oleh karena itu, perlu dilakukan sosialisasi dan pelatihan pengolahan makanan sumber protein kepada ibu balita. Sasaran dan luarannya adalah meningkatkan pengetahuan dan keterampilan ibu balita dalam mengolah pangan sumber protein menjadi berbagai produk olahan. Kegiatan ini terdiri dari beberapa tahapan seperti baseline data, advokasi, sosialisasi, pelatihan, dan evaluasi. Metodenya adalah ceramah, diskusi, dan demonstrasi. Tahap implementasi meliputi pemberian informasi tentang PMT sumber protein berbahan dasar ikan dan cara pengolahannya yang dikombinasikan dengan daun kelor. Hasil tes pengetahuan menunjukkan peningkatan pengetahuan ibu setelah pemberian materi sebesar 23\%. Kesimpulan dari kegiatan ini kongkrit bermanfaat bagi para ibu serta dapat memberikan dukungan dan motivasi bagi para ibu untuk terus menjaga asupan gizi anaknya. Disarankan kegiatan ini dilanjutkan untuk pengemasan dan pelabelan.
\end{abstract}

Kata Kunci: Balita, Demo Masak, Pelatihan

\begin{abstract}
The province of East Nusa Tenggara still first ranks in terms of nutrition (wasting, stunting, under weight of children under five). The factors causing nutritional problems in children under five are inadequate food processing and child care. Therefore, it is necessary to conduct socialization and training of protein source food processing to mothers of toddlers. Targets and outputs are to improve the knowledge and skills of mothers under five in processing protein source foods into various processed products. This service consists of several stages such as baseline data, advocacy, outreach, training, and evaluation. The methods are lectures, discussions, and demonstrations. The implementation phase includes providing information about PMT protein sources and processing methods for fish-based (jellyfish) combination of Moringa leaves. The results of the knowledge test showed an increase in the knowledge of mothers after giving the material by 23\%. The conclusion of this activity is concretely beneficial for mothers and can provide support and motivation for mothers to continue to maintain the nutritional intake of their children. It is recommended that this activity be continued for packaging and labeling.
\end{abstract}

Key Word: Children, Cooking Demo, Training. 


\section{Pendahuluan}

Masa balita merupakan masa growth spurth dimana terjadi pertumbuhan dan perkembangan otak yang optimal. Masalah gizi pada balita dapat menyebabkan gangguan tumbuh kembang anak, misalnya stunting, wasting dan gangguan perkembangan mental (Wirawan S, dkk, 2014).

Perkembangan masalah gizi di Indonesia semakin kompleks saat ini, selain masalah kekurangan gizi, masalah kelebihan gizi juga menjadi persoalan yang harus ditangani dengan serius. Berdasarkan data Riskesdas 2018, proporsi status gizi buruk, gizi kurang, pendek dan sangat pendek pada balita dari tahun 2013-2018, Nusa Tenggara Timur berada pada pada peringkat pertama (Mansbridge, 1998).

Menurut World Health Organization (WHO), dikemukan penyebab kematian anak diantaranya adalah komplikasi kelahiran prematur, pneumonia, asfiksia lahir, diare dan malaria. Diperkirakan sekitar 45\% dari seluruh kematian anak terkait dengan gizi buruk sehingga membuat anak lebih rentan terhadap penyakit (World Health Organization, 2015)

Banyak faktor yang mengakibatkan terjadinya masalah gizi. Ada dua faktor terjadinya masalah gizi menurut UNICEF, (1) Faktor langsung yaitu: kurangnya asupan gizi dari makanan, akibat terjadinya penyakit yang mengakibatkan infeksi dan (2). Faktor tidak langsung yaitu: ketersediaan pangan tingkat rumah tangga, perilaku dan budaya dalam pengolahan pangan dan pengasuh anak, pengelolahan lingkungan yang buruk dan pelayanan kesehatan yang tidak memadai (UNICEF, 1998)

Salah satu penyebab gizi kurang pada balita adalah tidak cukup mendapat makanan bergizi seimbang yang disebabkan rendahnya pengetahuan keluarga tentang gizi dan cara pengolahannya (Arifin, 2016). Untuk memperbaiki masalah gizi pada balita, tidak cukup hanya dengan memberikan PMT, tetapi juga dengan upaya peningkatan pengetahuan gizi keluarga. Meningkatnya pengetahuan dan cara pengolahan makanan sebagai intervensi boleh jadi akan diikuti dengan perubahan perilaku.

Ibu mempunyai peran yang sangat penting dalam tumbuh kembang balita terutama dalam hal pemberian makanan, untuk itu perlu adanya upaya seperti edukasi, pendampingan dan penyuluhan secara berkelanjutan dalam hal pengetahuan gizi dan pengolahan makanan dengan berbagai variasi sehingga dapat meningkatkan status gizi balitanya serta dapat menambah pendapatan keluarga keluarga (Yendi dkk., 2017). Penelitian Rachmayanti R D (2018) yang melakukan Intervensi kepada 38 ibu balita berupa health education menggunakan media leaflet, video dan simulasi membuat modisco (sebagai salah satu cara untuk membuat dan mengolah bahan makanan lokal yang lebih bergizi) menunjukkan hasil adanya peningkatan pengetahuan yang signifikan sebelum dan sesudah intervensi $(\mathrm{p}=0,043)$ (Rachmayanti, 2018). Begitupun dengan kegiatan pengabdian masyarakat oleh Rusyantia A dkk (2018) yang melakukan pelatihan Pembuatan MP-ASI WHO Berbasis Pangan Lokal Bagi Kader Posyandu dan Ibu Baduta diperoleh hasil terjadinya peningkatan pengetahuan dan keterampilan peserta sebesar $68,9 \%$ (Rusyantia, 2018) 
Oleh karena itu, untuk memperoleh asupan gizi yang baik secara kualitas dan kuantitas maka diperlukan peningkatan pengetahuan dan keterampilan ibu balita dalam mengolah makanan agar lebih bervariasi. Pengabdian masyarakat ini dilaksanakan untuk meningkatkan pengetahuan dan keterampilan ibu balita dalam mengolah makanan sumber protein berbahan dasar ikan menjadi berbagai produk olahan.

Kampung Nelayan Oesapa merupakan kawasan di pesisir pantai Oesapa, Kecamatan Kelapa Lima, Kota Kupang dimana pada wilayah ini masih banyak masalah gizi yang ditemukan seperti gizi kurang, stunting dll. Masalah gizi di Kelurahan Oesapa diduga dipengaruhi oleh banyak faktor antara lain pengetahuan ibu, pola asuh ibu, pendapatan keluarga dan kepadatan hunian. Pengetahuan gizi ibu yang kurang akan berpengaruh terhadap ketepatan pemilihan makanan yang bergizi untuk anaknya dan keluarganya (Ngoma dkk., 2019).

Berdasarkan hasil wawancara dengan ibu balita pada saat pengambilan besline data diketahui bahwa salah satu faktor yang mempengaruhi asupan makan yang kurang pada balita adalah kebiasaan mengkonsumsi makanan jajanan yang tidak sehat. Disamping itu tehnik pengolahan ikan yang sifatnya masih tradisional seperti dimasak dan digoreng biasanya kurang diminati oleh balita sehingga lebih cenderung memilih makanan jajanan. Keadaan ekonomi juga menjadi pemicu sehingga nelayan tradisional lebih memilih menjual ikan hasil tangkapannya daripada dikonsumsi sendiri.

Kurangnya pengetahuan dan kesadaran untuk berkreasi dan berinovasi menyebabkan sumberdaya yang ada tidak terolah secara maksimal, yang dapat menambah pendapatan keluarga (Intisari \& Rosnina, 2019). Untuk itu diperlukan upaya untuk mengatasi masalah tersebut salah satunya dengan melakukan sosialisasi tentang makanan sumber protein dan manfaatnya bagi tumbuh kembang balita. Selain itu, pelatihan pengolahan makanan khususnya hasil laut sumber protein perlu dilakukan bagi ibu balita agar pemberian makanan lebih bervariasi.

Target yang akan dicapai pada kegiatan pengabdian masyarakat ini adalah meningkatnya pengetahuan dan keterampilan ibu balita dalam mengolah makanan sumber protein berbahan dasar ikan menjadi berbagai produk olahan.

Luaran yang diharapkan pada kegiatan program pengabdian masyarakat ini berupa modul pelatihan pengolahan makanan berbasis ikan dan artikel yang dipublikasikan pada jurnal nasional terakreditasi.

\section{Metode}

Pengabdian kepada masyarakat dilaksanakan pada bulan September-November di Kampung Nelayan, Kelurahan Oesapa, Kota Kupang tahun 2020. Peserta kegiatan pengabmas ini adalah ibu balita. Rangkaian kegiatan pengabdian kepada masyarakat terdiri dari beberapa tahapan meliputi:

1. Baseline data: Kegiatan ini bertujuan untuk memperoleh data tentang karakteristik balita dan keluarganya.

2. Advokasi: Melakukan pertemuan dengan pejabat setempat dan kader posyandu untuk membicarakan tentang kegiatan yang akan dilaksanakan selama pengabdian. 
3. Sosialisasi pemberian PMT sumber protein. Sosialisasi dilakukan kepada ibu-ibu yang hadir pada posyandu mengenai pentingnya memperhatikan pemberian makanan yang baik bagi balita dalam meningkatkan status gizinya utamanya makanan sumber protein yang dapat dibuat dengan bahan dasar ikan yang banyak diperoleh di Kampung Nelayan Oesapa. Sosialisasi diberikan dalam bentuk ceramah singkat dan diskusi disertai pemberian resep. Pengetahuan ibu berkaitan dengan makanan sumber protein diukur menggunakan kegiatan pre test dan post test.

4. Pelatihan pengolahan makanan berbasis ikan: Pelatihan ini diikuti oleh ibu balita. Produk yang dibuat adalah nugget, bakso, tahu bakso, tahu walik dan empek-empek yang dikombinasikan dengan daun kelor. Materi dalam pelatihan ini adalah bahanbahan dan cara pembuatan dengan metode pelatihan ceramah, diskusi, demonstrasi dan prektek langsung.

5. Monitoring dan evaluasi: Setiap kegiatan yang dilakukan dimonitor dengan daftar hadir dan didokumentasikan kemudian dilakukan evaluasi untuk tindak lanjut berikutnya. Peningkatan pengetahuan dievaluasi menggunakan koesioner sebelum dan setelah pemberian materi.

\section{Hasil dan Pembahasan}

Adapun hasil yang dicapai dari pelaksanaan kegiatan pengabdian masyarakat sebagai berikut:

\section{Karakteristik Responden}

Data karakteristik responden dapat dilihat pada table di bawah ini:

Tabel 1. Besline data karakteristik responden

\begin{tabular}{lcc}
\hline \multicolumn{1}{c}{ Karakteristik Responden } & N (27) & $\mathbf{\%}$ \\
\hline Pendidikan Ibu: & 4 & \\
SD & 2 & 14.8 \\
SMP & 17 & 7.4 \\
SMA & 4 & 63.0 \\
Perguruan Tinggi & 21 & 14.8 \\
\hline Pekerjaan Ibu: & 5 & \\
IRT & 1 & 77.8 \\
Wiraswasta & & 18.5 \\
Honorer & 11 & 3.7 \\
\hline Status Tempat Tinggal: & 7 & \\
Rumah sendiri & 9 & 40.7 \\
Tinggal dengan famili lain & & 25.9 \\
Kos & 5 & 33.3 \\
\hline Umur Balita (Bulan): & 7 & \\
6 -12 & 5 & 18.5 \\
13 - 24 & 10 & 25.9 \\
25 - 36 & & 18.5 \\
> 36 & 11 & 37.0 \\
\hline Jenis Kelamin Balita: & 16 & \\
Laki - laki & & 40.7 \\
Perempuan & & 59.3 \\
\hline
\end{tabular}


Tabel 1 menunjukkan karakteristik responden berdasarkan tingkat pendidikan diperoleh hasil bahwa jumlah responden yang tingkat pendidikannya SMA lebih banyak yaitu 17 orang $(63 \%)$ dibandingkan dengan yang tingkat pendidikan lainnya. Tingkat pendidkan orang tua memegang peranan penting dalam kehidupan berkeluarga karena semakin tinggi tingkat pendidikan ayah dan ibu diharapkan pengetahuan gizi dan kesehatannya akan lebih baik sehingga memungkinkan dimilikinya informasi tentang gizi dan kesehatan yang lebih baik pula dan akan berdampak pada konsumsi pangan melalui cara pemilihan bahan pangan dan pengolahan makanan.

Karakteristik orang tua berdasarkan pekerjaan diketahui lebih banyak yang tidak bekerja atau berperan sebagai Ibu Rumah Tangga (IRT) yaitu 21 orang $(77,8 \%)$. Ibu yang tidak bekerja memiliki waktu lebih banyak yang dapat dihabiskan dengan anak mereka. Mereka dapat mengatur pola makan anak, melakukan variasi pengolahan makanan, melatih dan mendidik anak sehingga perkembangan anak lebih baik dibandingkan dengan ibu yang bekerja (Geofanny, 2016).

Karakteristik orang tua berdasarkan status kepemilikan tempat tinggal diketahui bahwa sampel paling banyak tinggal di rumah sendiri yaitu 11 orang $(40,7 \%)$ dan sisanya adalah tinggal dengan keluarga lain dan kos.

Karakteristik umur balita rata-rata berada pada kelompok umur 13-24 bulan dan $>$ 36 bulan yaitu 10 anak (37\%) dan terdapat 5 anak (18,5\%) berada pada kelompok umur 25-36 bulan. Karakteristik jenis kelamin balita perempuan 16 anak $(59,3 \%)$ lebih banyak dari balita laki-laki 11 anak (40,7\%).

\section{Sosialisasi pemberian PMT sumber protein.}

Kegiatan ini dilakukan di posyandu yang diikuti oleh ibu balita. Pemberian materi dalam bentuk ceramah dan tanya jawab mengenai manfaat protein bagi tumbuh kembang anak. Kemudian dilanjutkan dengan pembagian resep PMT berbahan dasar ikan yang bisa dikombinasikan dengan sayuran seperti daun kelor.

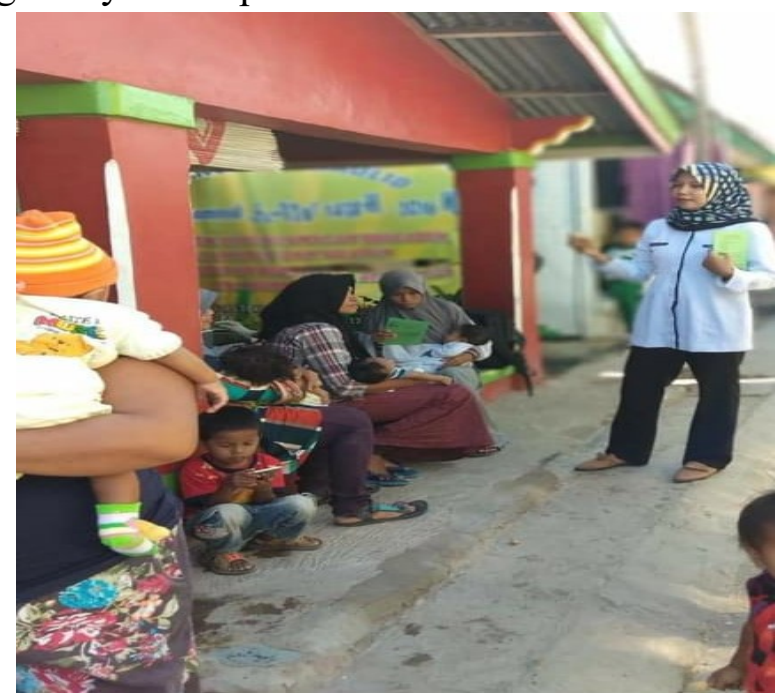

Gambar 1. Sosialisasi pemberian PMT sumber protein

Peningkatan pengetahuan sebelum dan setelah pemberian materi dapat dilihat pada gambar di bawah ini: 


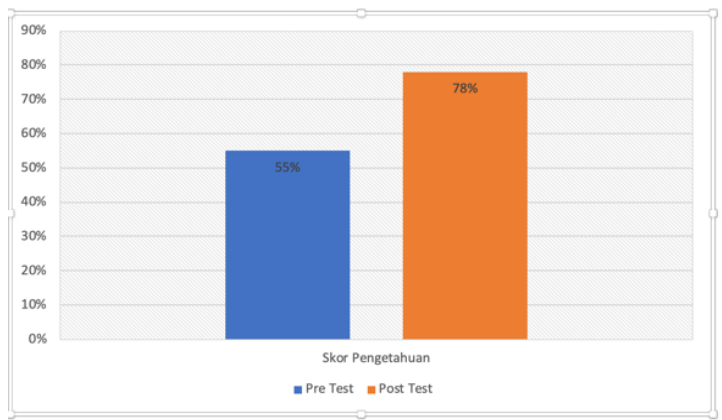

Gambar 2. Skor pengetahuan responden sebelum dan setelah pemberian materi

Gambar 2 menunjukkan terjadi peningkatan pengetahuan responden sebelum dan setelah pemberian materi dari 55\% menjadi 78\%. Kegiatan ini sejalan dengan penelitian yang dilakukan oleh Noor (2016) bahwa Ada pengaruh pendidikan gizi terhadap pengetahuan ibu dalam tumbuh kembang Balita usia 24-48 bulan di Wilayah Puskesmas Tanete Bulukumba (Noor dkk., 2016).

Pemberian informasi yang sifatnya edukatif akan meningkatkan pemahaman pribadi terhadap sebuah objek tertentu, karena orang yang menerima informasi tersebut akan memiliki pandangan yang berbeda dengan yang belum pernah mendengarnya (Notoatmodjo, 2007).

\section{Pelatihan Pengolahan Makanan Berbasis Ikan}

Kegiatan pelatihan ini dilakukan selama dua hari di rumah warga yang diikuti oleh ibu balita. Metode yang dilakukan adalah ceramah, diskusi, demonstrasi, praktek langsung dan pendampingan ibu balita. Materi dalam pelatihan ini adalah bahan-bahan dan cara pembuatan ikan seperti nugget, bakso, tahu bakso, tahu walik dan empek-empek yang dikombinasikan dengan daun kelor.

Sebelum pelatihan dimulai, terlebih dahulu ketua tim pengabmas membuka kegiatan dengan memberikan penjelasan mengenai kegiatan yang akan dilakukan dan manfaatnya bagi peserta. Setelah itu dilanjutkan dengan kegiatan demonstrasi oleh tim.

Kegiatan pelatihan juga ditunjang oleh media berupa leaflet/ brosur yang dibagikan kepada peserta yang hadir dimana isi dari leaflet tersebut berkaitan dengan edukasi mengenai kumpulan resep yang digunakan pada saat demonstrasi agar resep dapat diterapkan sendiri di rumah.

Peserta sangat antusias dalam mengikuti kegiatan ini ditandai dengan keaktifan dalam bertanya selama kegiatan demonstrasi. Dalam kegiatan demonstrasi, tim pengabdian menggunakan peralatan sederhana yang juga dimiliki oleh ibu balita sehingga tidak menyulitkan jika ingin dilakukan di rumah sekembalinya dari pelatihan ini. Bahan yang digunakan juga sangat mudah ditemukan seperti ikan tenggiri ataupun jenis ikan lainnya dikarenakan lokasi pengabmas berada di pesisir pantai Oesapa yang merupakan penghasil ikan di Kota Kupang.

Setelah kegiatan demonstrasi oleh tim pengabmas, kemudian dilanjutkan dengan praktek langsung oleh ibu balita dan didampingi oleh tim pengabmas. 
Pelatihan berlangsung selama dua hari dengan resep yang berbeda agar ibu balita dapat melihat secara langsung dan mempraktekkan beberapa variasi makanan olahan berbahan dasar ikan secara mandiri.

Kegiatan pelatihan ini dapat memberikan dampak berupa kemandirian dalam mengaplikasikan ilmu. Dalam hal ini ibu balita yang telah mengikuti pelatihan telah merasakan ada jiwa mandiri dalam dirinya. Mereka sudah mampu membuat produk olahan berbahan dasar ikan tanpa bantuan orang lain. Sejalan dengan pengabdian yang dilakukan oleh Rahmawati (2020) yang mengatakan bahwa Pelatihan dapat meningkatan pengetahuan, wawasan, keterampilan serta dapat memandirikan peserta dalam mengolah sagu menjadi produk yang bernilai ekonomi (Rahmawati dkk, 2020).

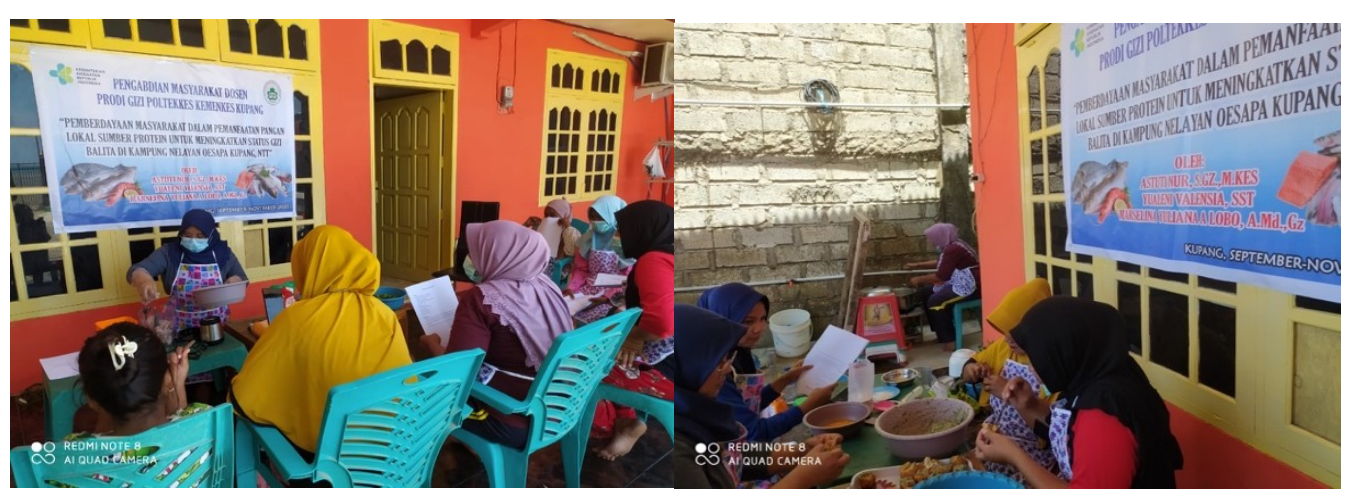

Gambar 3. Demonstrasi Pengolahan

Makanan Berbasis Ikan
Gambar 4. Praktek langsung oleh ibu balita

Adapun kendala yang dihadapi pada saat kegiatan ini adalah kegiatan ini dilaksanakan pada masa pandemic covid-19 sehingga tidak bisa mengumpulkan banyak peserta. Diharapkan setelah mengikuti kegiatan ini peserta dapat mengaplikasikan produk ini di rumah sehingga dapat memperbaiki status gizi balitanya.

Adapun kriteria sederhana dan menjadi tolak ukur dalam program pelatihan ini adalah :

1. Masyarakat mampu mengolah ikan berbahan menjadi jelly fish yang dapat dibuat berbagai jenis produk sesuai dengan yang diajarkan saat pelatihan

2. Semua peserta hadir dalam kegiatan pengabdian masyarakat yang dimonitor dengan daftar hadir dan didokumentasikan.

3. Terjadinya peningkatan pengetahuan peserta yang dievaluasi menggunakan koesioner sebelum dan setelah pemberian materi.

4. Diharapkan nantinya bisa menjadi home industry bagi masyarakat.

5. Diharapkan masyarakat bisa menjadi lebih produktif dalam meningkatkan perekonomian ke depannya.

\section{Kesimpulan}

Pelatihan pengolahan makanan berbasis ikan kepada ibu balita yang dilaksanakan di Kampung Nelayan Oesapa Kupang merupakan suatu bentuk pemberdayaan masyarakat dalam upaya meningkatkan derajat kesehatan ibu, bayi dan balita. Pelatihan 
ini secara konkrit dapat meningkatkan pengetahuan dan keterampilan ibu balita dalam mengolah makanan yang dapat memberikan dukungan dan motivasi ibu untuk terus menjaga asupan gizi balitanya.

Diharapkan agar kegiatan ini tidak berhenti sampai di sini tetapi dapat terus berlanjut terutama bagi ibu balita agar bisa melanjutkan secara mandiri. Rekomendasi untuk kegiatan selanjutnya adalah pelatihan pengemasan dan pelabelan agar bisa bernilai ekonomi dan menambah pemasukan masyarakat khususnya ibu balita.

\section{Ucapan Terimakasih}

Tim penulis mengucapkan terima kasih kepada Poltekkes Kemenkes Kupang yang telah mendanai pengabdian masyarakat ini.

\section{Daftar Pustaka}

Arifin, Z. (2016). Gambaran Pola Makan Anak Usia 3-5 Tahun Dengan Gizi Kurang Di Pondok Bersalin Tri Sakti Balong Tani Kecamatan Jabon -Sidoarjo. Midwiferia. https://doi.org/10.21070/mid.v1i1.345

Geofanny, R. (2016). Perbedaan Kemandirian Anak Usia Dini Ditinjau Dari Ibu Bekerja dan Ibu Tidak Bekerja. Psikoborneo.

Intisari, I., \& Rosnina, R. (2019). Pemberdayaan Masyarakat Melalui Pelatihan Berbagai Olahan Jantung Pisang Di Desa Pabbarasseng Kecamatan Bua Kabupaten Luwu. To Maega : Jurnal Pengabdian Masyarakat, 2(2), 31. https://doi.org/10.35914/tomaega.v2i2.240

Mansbridge, J. (1998). Skin substitutes to enhance wound healing. In Expert Opinion on Investigational Drugs (Vol. 7, Issue 5). https://doi.org/10.1517/13543784.7.5.803

Ngoma, D. N., Adu, A. A., \& Dodo, D. O. (2019). Faktor-Faktor yang Mempengaruhi Kejadian Gizi Kurang pada Balita di Kelurahan Oesapa Kota Kupang. Media Kesehatan Masyarakat. https://doi.org/10.35508/mkm.v1i2.1955

Noor, H. M., Marhaeni, \& Umar, S. (2016). Pengaruh pendidikan gizi terhadap pengetahuan ibu balita usia 24 - 48 bulan di wilayah puskesmas tanete kabupaten bulukumba. Jurnal Kebidanan.

Notoatmodjo, S. (2007). Promosi Kesehatan dan Ilmu Perilaku. Jakarta : Rineka Cipta. In Applied Nursing Research.

Rachmayanti, R. D. (2018). Peningkatan Pengetahuan Ibu Balita Melalui Pengenalan Program Kadarzi Di Kelurahan Wonokusumo Surabaya. Media Gizi Indonesia. https://doi.org/10.20473/mgi.v13i2.176-182

Rahmawati, R., Firmansyah, F., Syarif, A., \& Arwati, S. (2020). Penyuluhan dan Pelatihan Olahan Sagu Menjadi Produk Brownies Dan Cookies Pada Tim Penggerak Pkk Desa Purwosari Kecamatan Tomoni Timur Kabupaten Luwu Timur. To Maega | Jurnal Pengabdian Masyarakat, 23. https://doi.org/10.35914/tomaega.v3i1.278

Rusyantia, A. (2018). Pelatihan pembuatan mp-asi who berbasis pangan lokal bagi kader posyandu dan ibu baduta di desa sidosari. Sakai Sambayan Jurnal Pengabdian Kepada Masyarakat. https://doi.org/10.23960/jss.v2i2.67

UNICEF. (1998). the State of the World' $\mathrm{S}$ the State of the World' S Children. In 


\section{Children.}

World Health Organization (WHO). (2015). Trends in Maternal Mortality: 1990 to 2015,Trends in Maternal Mortality: 1990 to 2015. WHO, Geneva.

Yendi, yoseph denianus nong, Eka, ni luh putu, \& Maemunah, N. (2017). Hubungan Antara Peran Ibu Dalam Pemenuhan Gizi anak Dengan Status Gizi Anak Praekolah Di TK Dharma Wanita Persatuan 2 Tlogomas Kota Malang. Nursing News.

Wirawan S, dkk (2014). Penyuluhan dengan Media Audio Visual dan Konvensional terhadap Pengetahuan Ibu Anak Balita: J Kesehat Masy. 2014;10(1):80-7). 